\title{
Androgenic adult granulosa cell tumor with secondary amenorrhea and elevated luteinizing hormone
}

\author{
Kenji Niwa ${ }^{1 *}$, Ryuichiro Yano ${ }^{2}$, Sakae Mori ${ }^{3}$, Yoshio Yamaguchi ${ }^{3}$, Nozomi Narikawa ${ }^{3}$ and Takuji Tanaka ${ }^{4}$ \\ *Correspondence: kniwa.gujo913@gmail.com \\ 'Department of Obstetrics and Gynecology, Gujo City Hospital, Gujo-city, Gifu Pref, Japan. \\ ${ }^{2}$ Department of Obstetrics and Gynecology, Gifu University Post-graduate School of Medicine, Gifu-city, Gifu Pref, Japan. \\ ${ }^{3}$ Section of Laboratory Medicine, Gujo City Hospital, Gujo-city, Gifu Pref, Japan. \\ ${ }^{4}$ Director of The Tohkai Cytopathology Institute, Minami-Uzura, Gifu-city, Gifu Pref, Japan.
}

\begin{abstract}
Granulosa cell tumors (GCTs), adult type, are the most common type of ovarian sex cord tumors. Menstrual irregularity, even secondary amenorrhea is frequently observed in premenopausal women bearing GCTs with hormonal activity. We present here in an extremely rare case of adult GCT in a patient presenting with secondary amenorrhea and serum testosterone (Test) and luteinizing hormone $(\mathrm{LH})$ elevations, and decreased estradiol $\left(\mathrm{E}_{2}\right)$. A 32-year-old woman visited our hospital complaining of secondary amenorrhea two years after second delivery. Signs of virilisatoin, such as increased pubic hair and clitoromegaly were present. A pelvic ultrasound scan revealed a right adnexal solid mass measuring $2.9 \times 3.9 \mathrm{~cm}$. Under the working diagnosis of sexcord tumor, the woman underwent a laparoscopic surgery of a right salpingo-oophorectomy and the tumor was collected from the Douglas' pouch. The tumor was diagnosed as an adult-type GCT stage IA. Spontaneous menstruation occurred and serum levels of Test, LH, FSH and $\mathrm{E}_{2}$ showed normal ranges one month after surgery. The patient is now healthy without evidence of a recurrence 30 months after the surgery. Although s-Test and LH elevations in patients with GCT is rare and its mechanism is not clearly understood, monitoring of s-Test and LH may provide an additional tumor marker after conservative surgery in such patients.
\end{abstract}

Keywords: Granulosa cell tumor (GCT), ovary, androgenic, luteinizing hormone (LH), laparoscopic surgery

\section{Background}

Granulosa cell tumors (GCTs), adult type are the most common type of ovarian sex cord tumors and account for $1-2 \%$ of all ovarian tumors and 3-5\% of all ovarian malignancies [1]. GCTs are usually diagnosed in early clinical stage and are also renowned for late recurrences.

GCTs exhibits endocrine activity and many features of normal granulosa cells, including FSH-binding, a response to $\mathrm{FSH}$, and the secretion of estrogen, inhibin [2], progesterone, androgen $[1,3,4]$ and Müllerian inhibiting substance [5]. The presentation of an adult GCTs accompanied by endocrinological symptoms is often related to hyperestrogensim and varies according to the age of patient. In premenopausal women, menstrual irregularity, menorrhagia, or even secondary amenorrhea may be the initial manifestation of GCTs [6].

We report here an extremely rare case of GCT associated with secondary amenorrhea and elevated $\mathrm{LH}$ and testosterone.

\section{Case report}

A 32-year-old Japanese woman, gravida 2 para 2, visited our hospital complaining of secondary amenorrhea two years after second delivery. Signs of virilisataion, such as increased pubic hair and clitoromegaly were present. A pelvic ultrasound scan revealed a right adnexal solid mass measuring $2.9 \times 3.9 \mathrm{~cm}$. As shown in (Table 1), her serum LH and Test were elevated to 18.1
$\mathrm{mlU} / \mathrm{ml}$ (normal range: $1.76-10.24$ in follicular phase) and 2.09 $\mathrm{ng} / \mathrm{ml}$ (normal range: $0.11-0.47$ ) respectively; meanwhile her serum estradiol was relatively low: $33 \mathrm{pg} / \mathrm{ml}$ (normal range: 19226). Other hormones, such as FSH $(5.13 \mathrm{mIU} / \mathrm{ml})$ progesterone $(1.23 \mathrm{ng} / \mathrm{ml})$ and prolactin were within normal range. Findings of other routine laboratory tests and tumor markers [CA125, 6.0, CA19-9, 3.3 and CA72-4, $0.9(\mathrm{ng} / \mathrm{ml})$ ] were also within normal limits. Magnetic resonance image (MRI) showed a wellcircumscribed solid tumor producing high-intensity signals on T2-weighted (Figure 1). Whole body CT examinations showed no abnormal signs other than pelvic tumor.

Under the working diagnosis of sex-cord tumor, the woman underwent a laparoscopic surgery of a right salpingooophorectomy and the tumor was collected from the Douglas' pouch, using by an Endopouch ${ }^{\circledR}$. A small amount of ascites was also collected. Cytology of the cut-surface of the resected tumor suggested a sex-cord tumor (Figure 2). Macroscopically, the resected ovarian tumor was solid and yellow (Figure 3 ). Microscopically, the tumor consisted of monomorphilic small cells with a trabecular pattern separated by a fibrothecomatous stroma and coffee-bean like nuclei were frequently seen (Figure 4). The tumor cells had small amounts of cytoplasm, and pale and uniform nuclei with high cellular density and without cellular atypia. Cytology of ascites was negative. On immunohistocehmical evaluation, the tumor cells expressed 


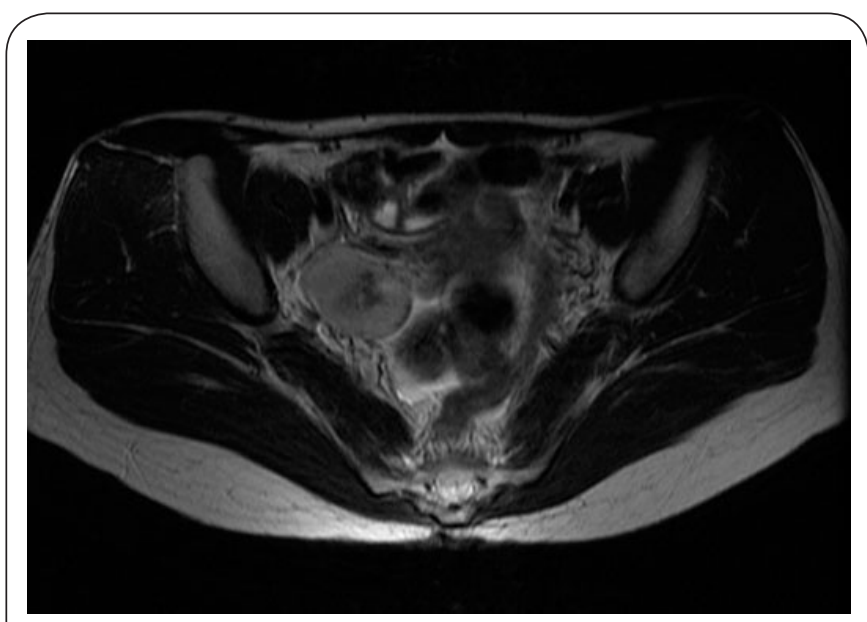

Figure 1. A well-circumscribed solid tumor $(3.9 \times 2.9 \mathrm{~cm})$ producing high-intensity signals on T2-weighted.

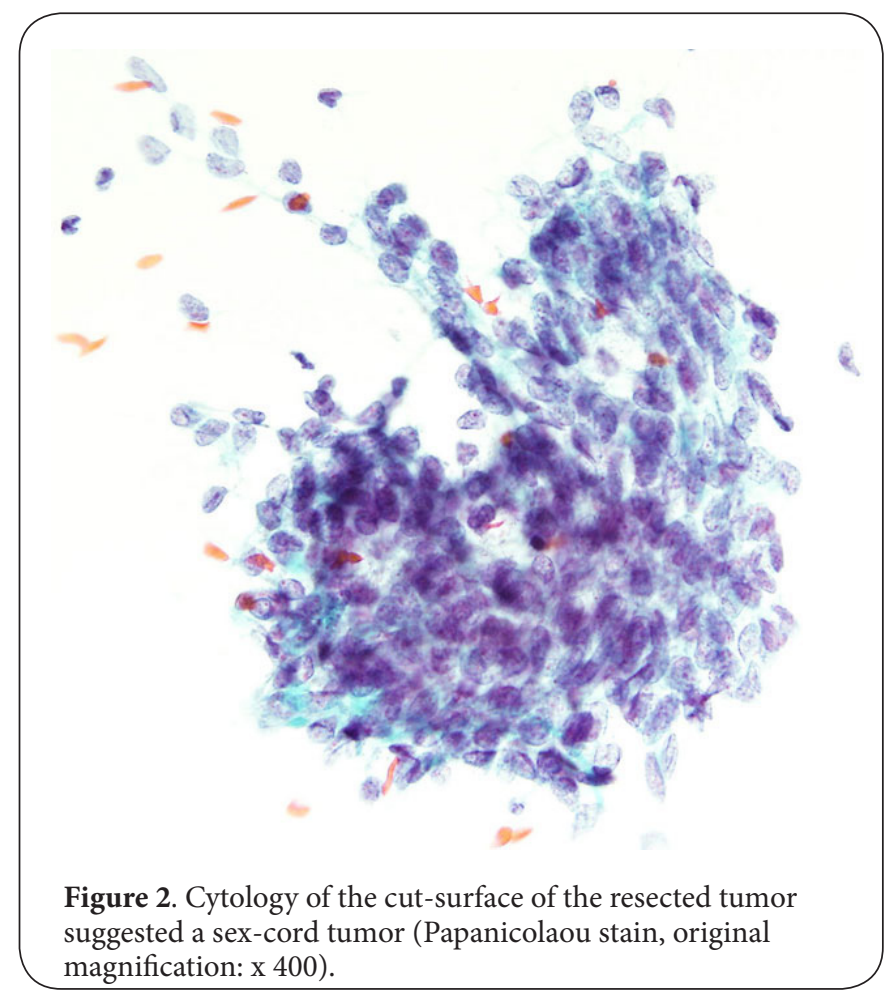

strong and diffuse staining for androgen receptor (Dako). The tumor cells showed positive staining for estrogen receptor (Dako) and focally positive for inhibin (Dako). Based on these findings, the tumor was diagnosed as an adult-type GCT stage IA (FIGO).

The changes of hormonal data are present in (Table 1). On the $5^{\text {th }}$ day after the surgery, s-Test decreased to the normal range, and the s-E2 increased to $60 \mathrm{pg} / \mathrm{dl}$ level. One month after the surgery, the hormonal levels showed normal womens' ones. Spontaneous menstruation occurred one month after the surgery. The patient showed no signs of recurrence and normal menstrual cycles 30 months after the surgery.

Table 1. Change of hormones.

\begin{tabular}{llll}
\hline & Pre-operative & $\begin{array}{l}\text { D5 after } \\
\text { surgery }\end{array}$ & $\begin{array}{l}\text { One month } \\
\text { after surgery }\end{array}$ \\
\hline $\begin{array}{l}\text { luteinizing hormone }(\mathrm{mIU} / \mathrm{mL}) \\
\begin{array}{l}\text { Follicle stimulating hormone } \\
(\mathrm{mIU} / \mathrm{mL})\end{array}\end{array}$ & $18.1 \uparrow$ & $24.4 \uparrow$ & 2.93 \\
Estradiol $(\mathrm{ng} / \mathrm{mL})$ & $19.5 \uparrow \uparrow$ & 2.46 \\
Progesterone $(\mathrm{ng} / \mathrm{mL})$ & $33 \downarrow \downarrow$ & $60 \downarrow$ & 171 \\
Testosterone $(\mathrm{ng} / \mathrm{mL})$ & 1.23 & 0.15 & $\mathrm{ND}^{*}$ \\
\hline
\end{tabular}

${ }^{\star} \mathrm{ND}$, not detremined.

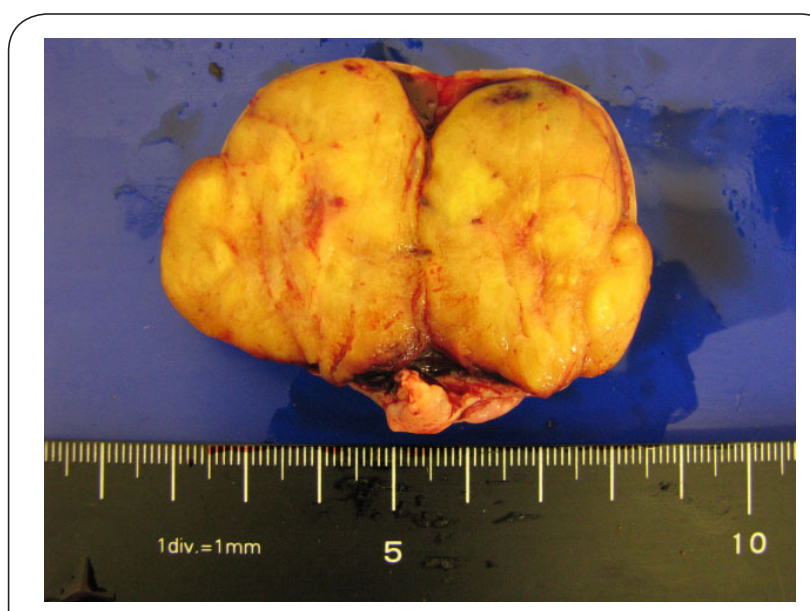

Figure 3. Macroscopically, the resected ovarian tumor was solid and yellow.

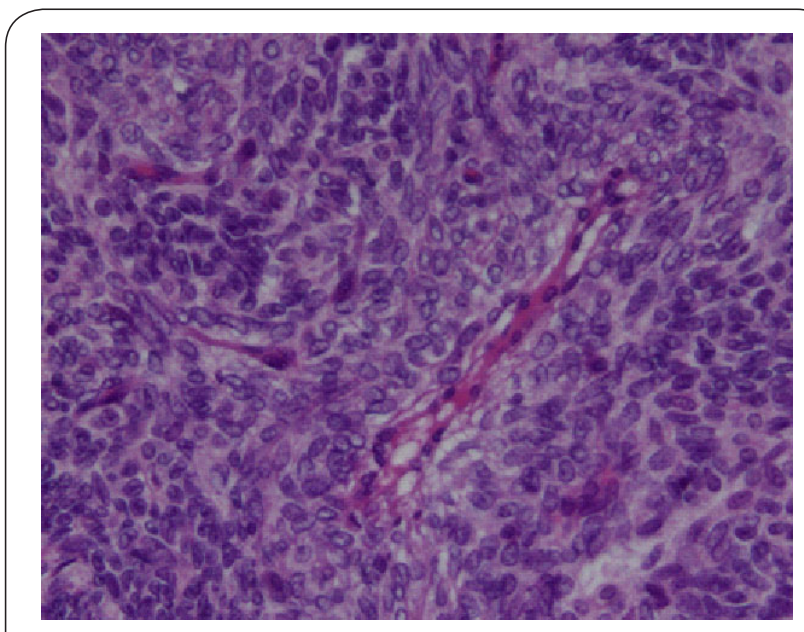

Figure 4. The tumor consisted of monomorphilic small cells with a trabecular pattern separated by a fibrothecomatous stroma (hematoxylin-eosin, original magnification: x 200). 


\section{Discussion}

We report here an extremely rare case of GCT associated with secondary amenorrhea. GCTs typically produce estrogen, however, in rare instances, they produce androgen. The clinical manifestations may be related to an excess androgen produced by GCTs. There have been several case reports of GCTs in which patients have presented with secondary amenorrhea $[2,6]$. Most of these cases were associated with baseline FSH levels and high inhibin levels, but serum $\mathrm{LH}$ and $\mathrm{E}_{2}$ levels were normal in many cases [2]. There have been only three cases of GCTs associated with high LH levels. The present case has shown clinically virilised and the pre-operatively elevated s-Test levels return to normal range following the removal of the ovarian tumor. In our case, an elevation of LH was thought be have interfered with normal follicular development and ovulation. LH levels returned to normal range and regular menstruation occurred after the surgery.

In polycystic ovary syndrome (PCO) cases, serum LH levels are high and secondary amenorrhea may occur. In the present case, the presence of hormonal disorders, such as PCOs were ruled out by the findings that the contralateral ovary showed a normal appearance and the LH level decreased immediately after the surgery.

The reason for the elevation of $\mathrm{LH}$ levels in the present case is not clear. Immunohistochemical examination of the GCT cells revealed the presence of androgen receptors. Based on the two-cell hypothesis of estrogen production, granulosa cells produce estradiol if the precursor Test is secreted by adjacent theca cells. However, in androgenic GCTs, few theca cells are present and it has been suggested that the granulosa cells lack aromatase activity to varying degrees. It has been reported that amenorrhea is the result of suppression of gonadotropins by the high levels of Test [7].

In the present case, high level of LH and normal level of FSH were present. The discrepancy of the LH and FSH levels, inhibin, a glycoprotein hormone suppress pituitary FSH production [2]. It can be suggested that the high s-Test induced atresia of follicles in the normal ovary, GCT replacing in the ovarian tissue, and resulted in secondary amenorrhea [8].

Unilateral oophorectomy is recommended treatment for women with GCT who wish to preserve their productive capacity [9]. GCTs are low potential malignant neoplasms with the capacity for local or lymphatic extension, particularly to the para-aortic lymph nodes [9]. Therefore, it is important to have a circulating marker as an early predictor or recurrent disease. Because an inhibin cannot be available in the clinical use, the serum LH may be a good marker for a recurrence in the present case.

\section{Conclusion}

An extremely rare case of adult type, granulosa cell tumor in a 32-year-old patient presenting with secondary amenorrhea and serum Test and LH elevations, and decreased $\mathrm{E}_{2}$ is reported. After a laparoscopic surgery of a right salpingo-oophorectomy, spontaneous menstruation soon occurred and serum levels of Test, $\mathrm{LH}$ and $\mathrm{E}_{2}$ showed normal ranges. The patient is now healthy without evidence of a recurrence 30 months after the surgery. Monitoring of s-Test and LH may provide an additional tumor marker after conservative surgery in such patients.

\section{Competing interests}

The authors declare that they have no competing interests.

\section{Authors' contributions}

\begin{tabular}{|l|c|c|c|c|c|c|}
\hline Authors' contributions & KN & RY & SM & YY & NN & TT \\
\hline Research concept and design & $\checkmark$ & -- & -- & -- & -- & - \\
\hline Collection and/or assembly of data & $\checkmark$ & $\checkmark$ & $\checkmark$ & $\checkmark$ & $\checkmark$ & -- \\
\hline Data analysis and interpretation & $\checkmark$ & $\checkmark$ & $\checkmark$ & $\checkmark$ & $\checkmark$ & - \\
\hline Writing the article & $\checkmark$ & -- & -- & -- & -- & - \\
\hline Critical revision of the article & $\checkmark$ & -- & -- & -- & -- & $\checkmark$ \\
\hline Final approval of article & $\checkmark$ & $\checkmark$ & $\checkmark$ & $\checkmark$ & $\checkmark$ & $\checkmark$ \\
\hline Statistical analysis & -- & -- & -- & -- & -- & - \\
\hline
\end{tabular}

\section{Acknowledgement}

We thank the editor and reviewers for their constructive comments, which helped us to improve the manuscript.

\section{Publication history}

Editor: Jingsong Yuan, The University of Texas, USA.

EIC: Markus H. Frank, Harvard Medical School, USA.

Received: 03-Nov-2013 Revised: 26-Nov-2013

Accepted: 10-Dec-2013 Published: 21-Dec-2013

\section{References}

1. Young RH and Scully RE. Endocrine tumors of the ovary. Curr Top Pathol. 1992; 85:113-64. | Article | PubMed

2. Lappohn RE, Burger HG, Bouma J, Bangah $M$, Krans $M$ and de Bruijn HW. Inhibin as a marker for granulosa-cell tumors. N Eng/ J Med. 1989; 321:790-3. | Article | PubMed

3. Honda T, Fukasawa H, Hashi A, Minai M, Hirata S and Hoshi K. Androgenic adult granulosa cell tumour with prolongation of the activated partial thromboplastin time in a 29 year old woman. BJOG. 2003; 110:433-5. | Article | PubMed

4. Nasu K, Fukuda J, Yoshimatsu J, Takai N, Kashima K and Narahara H. Granulosa cell tumor associated with secondary amenorrhea and serum luteinizing hormone elevation. Int J Clin Oncol. 2007; 12:228-30. I Article | PubMed

5. Gustafson ML, Lee MM, Scully RE, Moncure AC, Hirakawa T, Goodman A, Muntz HG, Donahoe PK, MacLaughlin DT and Fuller AF, Jr. Mullerian inhibiting substance as a marker for ovarian sex-cord tumor. $N$ Engl J Med. 1992; 326:466-71. | Article | PubMed

6. Schumer ST and Cannistra SA. Granulosa cell tumor of the ovary. I Clin Oncol. 2003; 21:1180-9. | Article | PubMed

7. Hatjis $\mathrm{CG}$, Polin JI, Wheeler JE and Hayes JM. Amenorrhea-galactorrhea associated with a testosterone-producing, solid granulosa cell tumor. Am J Obstet Gynecol. 1978; 131:226-7. | PubMed

8. Louvet JP, Harman SM, Schrieber JR and Ross GT. Evidence of a role of adrogens in follicular maturation. Endocrinology. 1975; 97:366-72. | Article | PubMed

9. Pfleiderer A. Therapy of ovarian malignant germ cell tumors and granulosa tumors. Int I Gynecol Pathol. 1993; 12:162-5. | Article I PubMed

\section{Citation:}

Niwa K, Yano R, Mori S, Yamaguchi Y, Narikawa N and Tanaka T. Androgenic adult granulosa cell tumor with secondary amenorrhea and elevated luteinizing hormone. Pathol Discov. 2013; 1:9.

http://dx.doi.org/10.7243/2052-7896-1-9 